\title{
FUNGSI SEL IMUN INTERLEUKIN-4 (IL-4) PADA IKAN KERAPU TIKUS (Cromileptes altivelis) DENGAN INDUKSI PROTEIN IMUNOGENIK Vibrio harveyi
}

\section{The FUNCTION OF INTERLEUKIN-4 (IL-4) IMMUNE CELLS ON HUMPBACK GROUPER (Cromileptes altivelis) BY INDUCTION OF IMMUNOGENIC PROTEIN OF Vibrio harveyi}

\author{
Uun Yanuhar, Asus Maizar SH dan Ita Fitria S \\ Fakultas Perikanan Dan Ilmu Kelautan, Universitas Brawijaya Malang \\ Jl. Veteran Malang, 65144 Telp. 081931892262
}

\begin{abstract}
Humpback grouper (Cromileptes altivelis) is a commodity to be cultivated because it has a high price, but the grouper highly susceptible to Vibriosis (Vibrio harveyi). The research objective was to see the function of immune cells of interleukin-4 (IL-4) are formed due to the induction of immunogenic proteins of Vibrio harveyi. Research procedures include Vibrio harveyi immunogenic protein isolation, SDS-PAGE electrophoresis, elektroelusi and dialysis, clinical exam of Vibrio harveyi immunogenic proteins, and immunohistochemical to look at immune cells (cells IL-4) with using a secondary antibody labeling of anti IL-4 biotin conjugate. The results showed that Vibrio harveyi protein found have immunogenic properties is $51.16 \mathrm{kDa}$. This protein is an adhesin protein. Protein $51.16 \mathrm{kDa}$ was purified by electroelution and the protein will be used as a vaccine administered by intraperitoneal injection in grouper (Cromileptes altivelis) at a dose of $31.6 \mathrm{ug}$ protein / $150 \mathrm{~g}$ of fish weight. In organ tissues of the brain, eyes and kidneys of induced fish by immunohistochemical examination, It was detected Immune cells (cells IL-4) using a secondary antibody labeling of anti IL-4 biotin conjugate. Tues formed IL-4 can be seen on the network grouper indicated by a change in tissue color with an inverted microscope examination of the golden brown color is formed on the IL-4 immune cells. It show the cross-reaction between $51.16 \mathrm{kDa}$ immunogenic protein induced in fish with anti IL-4 biotin conjugate. The conclusions is the protein of Vibrio harveyi with molecular weight of $51.16 \mathrm{kDa}$ is an immunogenic protein which able to induce formation of IL-4 in grouper.
\end{abstract}

Keywords : Cromileptes altivelis, Immunohistochemistry, IL-4 cells, V. harveyi

\section{Pendahuluan}

Ikan kerapu tersebar luas di perairan pantai baik di daerah tropis maupun sub tropis, dan termasuk jenis ikan yang hidup di perairan berkarang sehingga sering dikenal sebagai ikan karang (coral reef fish). Beberapa jenis ikan kerapu yang banyak terdapat di Indonesia seperti kerapu bebek atau tikus (Cromileptes altivelis), kerapu macan (Epinephelus fuscoguttatus), kerapu sunu (Plectropomus leopardus), kerapu lumpur (Epinephelus coioides), kerapu malabar (Epinephelus malabaricus), dan kerapu bintik atau batik (Epinephelus bleekeri), merupakan komoditas andalan untuk dibudidayakan karena memiliki nilai jual yang tinggi (Aslianti, et al., 2003).

Vibrio merupakan patogen oportunistik yang dalam keadaan normal ada dalam lingkungan pemeliharaan, kemudian berkembang dari sifat yang saprofitik menjadi patogenik jika kondisi lingkungannya memungkinkan. Bakteri vibrio yang patogen dapat hidup di bagian tubuh organisme lain baik di luar tubuh dengan jalan menempel, maupun pada organ tubuh bagian dalam seperti hati, usus dan sebagainya (Feliatra, 1999). Salah satu spesies dari Vibrio yang menyebabkan Vibriosis adalah bakteri Vibrio harveyi (Jun et al, 2003).

Respon yang diakibatkan oleh bakteri Vibrio harveyi khususnya pada ikan kerapu tikus (Cromileptes altivelis) perlu dilakukan penelitian mengenai respon ekstraseluler protein reseptor untuk meningkatkan sistem kekebalan tubuh ikan yang tahan terhadap penyakit. Respon molekul tubuh dalam mengeliminasi antigen diantaranya adalah dengan membentuk sel imun baik interleukin maupun MHC (Abas \& Lichtman, 2005).

MHC (Major Hstocompatibility Complex) merupakan salah satu molekul yang berperan penting dalam sistem pertahanan adaptif. Ketika antigen dipresentasikan oleh MHC, antigen akan ditangkap oleh reseptor pada sel T helper (2), dan sel T helper (2) akan mensekresikan sitokin yaitu IL-2, 4, 6 yang bertujuan untuk diferensiasi dan proliferasi sel B, diferensiasi sel B akan menghasilkan sel plasma dan sel memori. Selanjutnya sel plasma 
akan mensintesis antibodi yang spesifik yang akan mengikat antigen sehingga mencegah pergerakannya, dan memudahkan fagositosis (Baratawidjaja, 1996).

Salah satu sitokin yang berperan dalam menstimulasi proliferasi dan diferensiasi sel B adalah interleukin 4 (IL-4). Oleh karena itu, dalam penellitian ini akan dilakukan pengamatan ekspresi IL-4 pada ikan kerapu tikus (Cromileptes altivelis) yang dipapar protein adesin Vibrio harveyi.

\section{Metodologi}

Materi penelitian adalah ikan kerapu tikus (Cromileptes altivelis), protein imunogenik bakteri Vibrio harveyi $51,6 \mathrm{kDa}$ dan sel interleukin-4.

Peralatan yang digunakan dalam penelitian ini meliputi $\mathrm{pH}$ meter, refraktometer, temometer, pembakar bunsen, pipet tetes, beaker glass, erlenmeyer, mortar, laminary air flow, sectio set, masker, gloves, eppendorf 1,5 $\mathrm{ml}$, falcon $15 \mathrm{ml}$ dan $50 \mathrm{ml}$, mikropipet $20 \mu \mathrm{l}$, $200 \mu \mathrm{l}$ dan $1000 \mu \mathrm{l}$, blue tip, yellow tip, freezer $80{ }^{\circ} \mathrm{C}$, aluminium foil, kapas, kertas label, sentrifuge $4^{0} \mathrm{C}$, refrigerator $4^{0} \mathrm{C}$, spuit $1 \mathrm{cc}$, timbangan analitik, tabung reaksi, cawan petri, magnetik stirrer, sendok erlenmeyer, chamber dot blot, seperangkat elektroforesis (SDSPAGE), baki/nampan, kotak penyimpan gel, kamera digital.

Bahan yang digunakan adalah ikan kerapu tikus (Cromileptes altivelis) normal dan ikan kerapu tikus yang positif terinfeksi bakteri Vibrio Harveyi, buffer ekstrak, PBS (Phospat Buffer Saline), alkaline phospatase subtrat (chromogen NBT) dan aquadest, stacking gel $5 \%$ yang meliputi : akrilamid 30\%, Tris HCL $1.5 \mathrm{M}$ pH 6.8, $\mathrm{dH}_{2} \mathrm{O}$, SDS (Sodium Dodecyl Sulfate) 10\%, APS (Ammonium Persulfat) 10\%, TEMED (tetra ethylene diamine); separating gel $12,5 \%$ dengan komposisi meliputi :

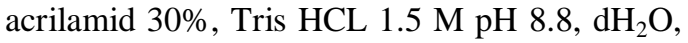
SDS (Sodium Dodecyl Sulfate) 10\%, APS (Ammonium Persulfat) 10\%, TEMED (tetra ethylene diamine); RSB (Reducing Sampel Buffer) dengan perbandingan 1:1 (RSB : sampel); marker PRO-STAIN ${ }^{\text {TM}}$; staining solution (commasie blue) dan destaining solution (metanol; asam asetat glasias; aquades), running buffer, es batu dan aquades.

Metode yang digunakan adalah metode eksplorasi laboratorium, dengan prosedur penelitian seperti berikut.
Aklimatisasi Ikan Kerapu Tikus (Cromileptes altivelis)

Ikan uji yang digunakan yaitu ikan kerapu tikus (Cromileptes altivelis) yang didatangkan dari Balai Pembenihan Air Payau (BPAP) di Situbondo. Ikan kerapu tikus (Cromileptes altivelis) yang digunakan berukuran antara 10-15 cm. Benih ikan kerapu tikus (Cromileptes altivelis) yang baru datang tidak langsung diberikan pakan, karena benih ikan kerapu tikus (Cromileptes altivelis) memerlukan adaptasi terhadap media pemeliharaannya yang baru. Adaptasi ini dibutuhkan selama 12 jam, pakan diberikan setelah ikan terlihat sehat dan agresif. Pakan yang digunakan berupa ikan kembung segar yang dicacah kecil-kecil. Pemberian pakan dilakukan sebanyak dua kali per hari, yaitu pada jam 08.00 dan 15.00 WIB. Selain itu setiap harinya dilakukan pengukuran parameter pendukung seperti suhu, salinitas dan $\mathrm{pH}$ untuk menjaga agar kondisi lingkungan Ikan kerapu tikus (Cromileptes altivelis) tetap normal. Adapun pengukuran parameter pendukung kualitas air yang secara otomatis terkontrol antara lain suhu, Sali nitas dan $\mathrm{pH}$.

Isolasi Bakteri Vibrio harveyi

$$
\text { Isolasi Bakteri Vibrio harveyi }
$$
didatangkan dari Jepara dan dilakukan perbanyakan kultur di laboratorium mikrobiologi Fak. Kedokteran Universitas Brawijaya. Bakteri dikultur pada medium TCBS dan BHI kemudian dilakukan penentuan konsentrasi bakteri dengan spektrofotometer untuk pengujian lebih lanjut.

Isolasi Crude Protein Vibrio harveyi

Crude protein Vibrio harveyi diisolasi dari kultur bakteri dengan metode isolasi crude protein untuk mendapatkan homogenat protein.

Homogenat protein yang didapat selanjutnya disentrifus dengan kecepatan 50.000 rpm selama 1 jam pada suhu $4^{0} \mathrm{C}$ dan dilanjutkan dengan $150.000 \mathrm{rpm}$ selama 3 jam pada suhu $4{ }^{0} \mathrm{C}$ dengan menggunakan Ultrahigh centrifuge (Optima ${ }^{\mathrm{TM}}$ MAX-XP, Beckman Coulter, USA). Crude protein Vibrio harveyi dan ikan normal disimpan dalam deepfreezer $80^{\circ} \mathrm{C}$ hingga untuk pengujian selanjutnya. Pellet yang dihasilkan merupakan whole cell sedangkan supernatan adalah crude protein bakteri Vibrio harveyi.

Elektroforesi Protein dengan SDS-Page

Untuk isolasi protein dilakukan metode elekroforesis menggunakan SDS-PAGE (Biorad). Gel terdiri dari dua lapis yaitu separating gel (gel sebagai media pemisah protein) dan stacking gel (gel pengumpul 
sampel). Dalam separating gel komposisi yang dipakai acrilamide $30 \%$, Tris HCL $1.5 \mathrm{M} \mathrm{pH}$ 8.8, $\mathrm{dH}_{2} \mathrm{O}$, SDS (Sodium Dodecil Sulfate) 10\%, APS (Ammonium Persulfat) 10\%, TEMED (tetra ethylene diamine). Sedangkan dalam stacking gel acrilamide 30\%, Tris HCL $1.5 \mathrm{M}$ $\mathrm{pH}$ 6.8, $\mathrm{dH}_{2} \mathrm{O}$, SDS (Sodium Dodecil Sulfate) 10\%, APS (Ammonium Persulfat) 10\%, TEMED (tetra ethylene diamine). Larutan separating gel yang telah dibuat dalam Erlenmeyer dituangkan ke dalam plate pembentuk gel menggunakan pipet (dijaga jangan sampai terbentuk gelembung udara) sampai tiga perempat tinggi plate. Perlahan dituangkan air diatas larutan gel agar permukaan gel tidak bergelombangm dan dibiarkan memadat selama kurang lebih 10 menit. Setelah itu air yang menutup separating gel dibuang. Selama menunggu separating gel memadat, stacking gel disiapkan kedalam erlenmeyer. Selanjutnya segera dituangkan larutan kedalam plate pembentuk gel menggunakan pipet sampai plate penuh. Perlahan diselipkan sisir pembentuk sumur sampel kedalam stacking gel segera setelah dituang. Setelah gel memadat sekitar 15 menit, sisir diangkat.

Sampel protein dipanaskan $100^{\circ} \mathrm{C}$ selama 5 menit, sebagai bahan warna adalah RSB dengan perbandingan 1:1. Sampel dimasukkan sumuran gel menggunakan mikropipet per sumuran masing - masing $18 \mu \mathrm{l}$ kemudian dielektroforesis dengan Voltage $90 \mathrm{~V}$, $400 \mathrm{~mA}$, selama 120 menit. Selanjutnya gel diangkat dari chamber, pewarnaan dilakukan dengan merendam dalam staining solution selama 1 jam sambil di shaker atau digoyanggoyang secara manual. setelah itu di hentikan pewarnaan dengan destaining solution dan kemudian diamati.

Gel hasil SDS PAGE dianalisa dengan cara menghitung band yang muncul. Dari hasil pewarnaan gel akan diperoleh hasil elektrogram yang berupa pita-pita protein. Pada elektrogram diukur jarak pergerakan masing-masing protein standar (marker) dan dicatat nilai Rf-nya dimana $\mathrm{Rf}$ merupakan perbandingan antara jarak pergerakan pita dari tempat awal dengan jarak pergerakan warna dari tempat warna.

Selanjutnya untuk membuat kurva kalibrasi berat molekul, nilai Rf ditempatkan sebagai sumbu $\mathrm{Y}$ dan berat molekul yang biasanya dinyatakan sebagai fungsi dari log berat molekul ditempatkan sebagai sumbu X. Grafik yang didapatkan berupa grafik linier dengan persamaan garis $y=a+b x$. Mobilitas dari suatu protein yang belum diketahui berat molekulnya dapat diukur dengan rumus diatas dan berat molekulnya dapat dicari dengan mengeplotkan langsung pada kurva standart berat molekul atau dapat dihitung dengan menggunakan persamaan garis dari kurva standart berat molekul.

Berat molekul pita protein yang telah dihitung menggunakan persamaan linear dari jarak sparating gel. Kemudian pita protein dari Vibrio harveyi diseleksi untuk digunakan sebagai kandidat protein adhesin berdasarkan dari pita major yang muncul dan tidak bergandeng dengan pita protein yang lain (nondimer). Pemotongan pita protein meggunakan pemotong gel. Gel yang telah dipotong disimpan dalam larutan running buffer untuk dilakukan elusi.

Elektroelusi dan Dialisa Protein

Kandidat protein adhesin Vibrio harveyi pada pita protein dipisahkan dengan metode elektroelusi menggunakan horisontal electroforesis (Biorad). Potongan-potongan gel dari masing-masing kandidat protein adhesin dimasukkan dalam membran celofan kemudian dielektroforesis pada $120 \mathrm{~V}, 400 \mathrm{~mA}$ selama 120 menit.

Protein selanjutnya didialisa dalam larutan PBS pH 7,4 pada suhu $4{ }^{0} \mathrm{C}$ selama 48 jam. Cairan dalam kantung selofan selanjutnya diambil dan dimasukkan dalam mikrotube dan dipresipitasi dengan menginkubasi pada larutan aceton (1:1 v/v) semalam pada suhu $4{ }^{0} \mathrm{C}$. Campuran protein dan aceton selanjutnya disentrifus pada $12.000 \mathrm{rpm}$ selama 20 menit pada suhu $4{ }^{0} \mathrm{C}$. Protein didapatkan dalam bentuk pellet, dikeringanginkan dan dilarutkan dalam $100 \mu \mathrm{l}$ tris $\mathrm{HCl} 0,5 \mathrm{M}, \mathrm{pH}$ 8,6. Selanjutnya dilakukan pengukuran konsentrasi protein menggunakan Nanodrop Spectrophotometry ND 1000 dengan Absorbansi 1 pada $280 \mathrm{~nm}$.

Pengujian Protein Imunogenik Pada Ikan Kerapu Tikus (Cromileptes altivelis)

Protein yang menunjukkan nilai hemaglutinasi paling tinggi dari Vibrio harveyi selanjutnya dilakukan uji klinis pada ikan kerapu tikus (Cromileptes altivelis) untuk mendapatkan antibodi anti-protein adhesin Vibrio harveyi. Uji klinis dilakukan dengan menggunakan 4 ekor ikan kerapu (ukuran 150$200 \mathrm{~g}$ ) untuk protein imunogenik Vibrio harveyi serta 4 ekor lainnya digunakan untuk kontrol (ikan normal). Sebelum perlakuan injeksi, ikan diaklimatisasi terlebih dahulu selama 1 bulan.

Protein imunogeik dari Vibrio harveyi disuntikkan secara intra peritoneal (i.p) dengan konsentrasi $33 \mathrm{~g} / 150 \mathrm{~g}$ ikan dengan volume 0,1 ml/ikan. Penyuntikan dilakukan dengan mencampurkan protein adhesin dengan 
Complete Freund's adjuvant (CFA) (1:1 v/v). Tujuh hari setelah penyuntikan pertama dilakukan penyuntikan kedua (booster) dengan volume dan konsentrasi protein yang sama dengan penambahan Incomplete Freund's adjuvant (IFA). Ikan dipelihara selama 14 hari dengan pemberian pakan menggunakan ikan rucah hingga kenyang (ad libitum) dengan aerasi dan pergantian air sekitar. Serum dari masing-masing ikan perlakuan dan kontrol didapatkan dengan mengambil darahnya pada hari ke-14 setelah injeksi pertama. Darah disentrifus pada $10.000 \mathrm{rpm}$ selama 10 menit pada suhu $4{ }^{0} \mathrm{C}$ untuk mendapatkan serumnya. Serum disimpan dalam $-20{ }^{0} \mathrm{C}$ hingga untuk pengujian berikutnya.

Pemeriksaan Imunohistokimia dengan Pelabelan Secondary Antibodi Anti IL-4 Conjugate Biotin

Uji Imunohistokimia untuk deteksi antigen dengue pada head squash (apusan sel/jaringan). Preparat head squash (apusan sel/jaringan) difiksasi dengan methanol dingin 3-5 menit, selanjutnya ditetesi Peroxidase blocking solution $\left(\mathrm{H}_{2} \mathrm{O}_{2}\right) 10$ menit. Diberi prediluted blocking serum (protein blocker) 15 menit, kemudian dikeringkan. Dan inkubasi dengan Antibodi primer (antibodi monoklonal DSSC7) semalam pada $4^{0} \mathrm{C}$. Selanjutnya cuci dengan PBS (phospat buffer saline) segar 3x masing-masing 2 menit kemudian keringkan dengan tisu langsung tungkan objek glass ke atas tisu. Diinkubasi lagi dengan Biotinylated universal secondary antibody (antibodi sekunder anti tikus) 20 menit pada suhu ruang, selanjutnya cuci dengan PBS segar 3x masingmasing 2 menit kemudian keringkan, ditetesi dengan Trekavidin-HRP 10 menit. Cuci dengan PBS segar 3x masing-masing 2 menit kemudian keringkan selama 3 menit. Siapkan betazoid DAB chromogen solution dengan mencampur 1 $\mu 1$ DAB chromogen dengan substrat buffer 100 $\mu \mathrm{l}$ kemudian teteskan pada preparat selama 5 menit cuci dibawah air kran, kemudian keringkan selama 3 menit. Tetesi dengan Mayer hematoxilen 1 menit sebagai counterstain inti berwarna biru. cuci dibawah air kran, selanjutnya dehidrasi dengan ethanol $100 \%$ sekali, clearing dengan Xylen atau Xylol sekali. Tetesi dengan entelan sebagai Mounting media, tutup dengan cover slip, periksa dibawah mikroskop cahaya perbesaran lemah, sedang dan kuat.

\section{Hasil dan Pembahasan}

Hasil penelitian ini meliputi hasil elektroforesis pita protein Vibrio harveyi dengan Sodium Dodecyl Sulfate Polyacrylamid Gel Elektrophoresis (SDS-PAGE) sehingga diperoleh protein imunogenik dari Vibrio harveyi ( Yanuhar, 2008). Protein imunogenik yang dihasilkan akan digunakan untuk pembosteran pada ikan kerapu tikus (Cromileptes altivelis) untuk menentukan ekspresi sel imun yakni sel IL-4. Fungsi sel imun yakni terbentuknya sel IL-4 dilakukan dengan melakukan preparasi jaringan dengan menggunakan teknik IHC dan pelabelan seconadary antibody anti CD4 conjugate biotin pada jaringan dari organ yang ditentukan yakni mata ,otak dan ginjal.

Hasil Elektroforesis Pita Protein Imunogenik Vibrio harveyi

Ekspresi infeksi $V$ harveyi pada level protein akan terdeteksi dengan menggunakan SDS-PAGE. Hasil elektroforesis dengan menggunakan gel poliakrilamid $12.5 \%$ terhadap crude protein Vibrio harveyi memberikan gambaran pita protein yang terdiri dari enam belas pita protein dengan berat molekul masingmasing yaitu $160.06 \mathrm{kDa}, 129.58 \mathrm{kDa}, 114.16$ $\mathrm{kDa}, 109.44 \mathrm{kDa}, 100.57 \mathrm{kDa}, 96.41 \mathrm{kDa}, 88.60$ $\mathrm{kDa}, 81.42 \mathrm{kDa}, 78.05 \mathrm{kDa}, 74.82 \mathrm{kDa}, 65.92$ $\mathrm{kDa}, 58.07 \mathrm{kDa}, 51.16 \mathrm{kDa}, 49.04 \mathrm{kDa}, 38.06$ $\mathrm{kDa}$ dan $36.49 \mathrm{kDa}$. Gambar hasil elektroforesis tersebut disajikan pada Gambar 1.

Protein imunogenik adalah protein yang bila dimasukkan dalam suatu sel atau organism akan membangkitkan fungsi dalam system imun komplek. Sistem imun ini berfungsi untuk memproteksi diri pada ikan yang telah di imunisasi terhadap antigen yang bersifat pathogen yang telah masuk.

Pita-pita protein tersebut di atas dipotong untuk dilakukan elektroelusi untuk memisahkan protein dari matriks gel. Protein yang telah dipisahkan dari matriks gel didialisa untuk pencucian dengan PBS dan dipresipitasi dengan aceton. Protein-protein spesifik tersebut disimpan dalam freezer $-20{ }^{0} \mathrm{C}$ hingga digunakan sebagai protein imunogenik dari Vibrio harveyi untuk pemboosteran ikan kerapu tikus. 


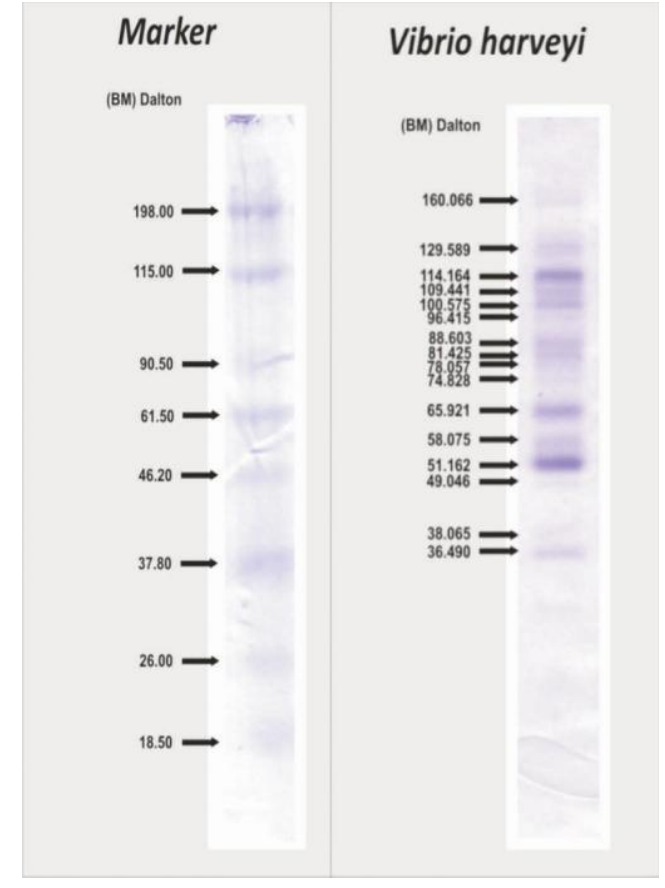

Gambar 1. Hasil elektrofresis pita protein imunogenik Vibrio harveyi

\author{
Keterangan: a. Marker Pro STAIN ${ }^{\mathrm{TM}}$ \\ b. Berat molekul (BM) crude \\ protein V.harveyi
}

Pita protein $51.162 \mathrm{kDa}$ adalah potein imunogenik dari Vibrio harveyi yang digunakan untuk pemboosteran Ikan kerapu tikus (Cromileptes altivelis)

Imunisasi Ikan Kerapu Tikus (Cromileptes altivelis) Secara Invivo Dengan Protein Imunogenik Betak Moleku 51,16 kDa

Protein imunogenik dari Vibrio harveyi disuntikkan secara intra peritoneal (i.p) dengan konsentrasi $33 \mathrm{~g} / 150 \mathrm{~g}$ ikan dengan volume 0,1 $\mathrm{ml} /$ ikan. Penyuntikan dilakukan dengan mencampurkan protein adhesin dengan Complete Freund's adjuvant (CFA) (1:1 v/v). Tujuh hari setelah penyuntikan pertama dilakukan penyuntikan kedua (booster) dengan volume dan konsentrasi protein yang sama dengan penambahan Incomplete Freund's adjuvant (IFA). Ikan dipelihara selama 14 hari dengan pemberian pakan menggunakan ikan rucah hingga kenyang (ad libitum) dengan aerasi dan pergantian air sekitar. Serum dari masing-masing ikan perlakuan dan kontrol didapatkan dengan mengambil darahnya pada hari ke-14 setelah injeksi pertama. Darah disentrifus pada $10.000 \mathrm{rpm}$ selama 10 menit pada suhu $4{ }^{0} \mathrm{C}$ untuk mendapatkan serumnya.
Serum disimpan dalam $-20{ }^{0} \mathrm{C}$ hingga untuk pengujian berikutnya

Pemboosteran pada ikan kerapu tikus (Cromileptes altivelis) dilakukan sebanyak tiga kali yaitu pemboosteran 1 selama 7 hari, pemboosteran 2 selama 14 hari, pemboosteran 3 selama 21 hari, seperti Gambar 2.

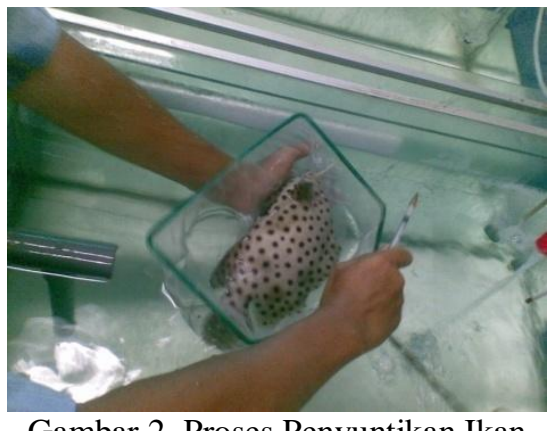

Gambar 2. Proses Penyuntikan Ikan

Dosis yang digunakan dalam penyuntikan ikan sebanyak 31,6 $\mu \mathrm{L}$. banyaknya dosis yang disuntikkan ini tergantuk dari kepadatan protein dan berat badan ikan.

Gejala yang timbul adalah ikan menunjukkan gejala stres, hilangnya nafsu makan, perubahan warna kulit menjadi lebih gelap serta perubahan perilaku. Infeksi ini bertujuan untuk mendapatkan antibodi ikan secara maksimal yang akan digunakan untuk uji pathogenesis selanjutnya.

Penggunaan ikan kerapu tikus dengan ukuran sekitar $150 \mathrm{~g}$ dalam uji klinis diharapkan bahwa ikan pada ukuran tersebut telah memiliki sistem imun yang sempurna sehingga produksi sel-sel dan molekul-molekul yang berperan dalam sistem imun ikan kerapu ikan dilakukan secara optimal. Disamping itu, penggunaan ikan dengan ukuran besar akan memudahkan dalam pengambilan darah dan jaringan organ.

Pemeriksaan Sel Interleukin-4 (IL-4) Pada Jaringan Dengan Teknik Imunohistokimiam (IHC)

Preparasi jaringan ikan kerapu tikus (Cromileptes altivelis yang terinfeksi Vibrio harveyi untuk mendeteksi sel IL-4 diperlakukan dengan menggunakan PFA 4\% dan dilakukan pencucian dengan PBS sebanyak 3 kali menggunakan DEPC dan secara steril, kemudian dilanjutkan dengan inkubasi pada larutan DEPC-sukrose 20\%, agar protein yang terekspresi tidak terkontaminasi, selanjutnya sampel siap dipotong dengan mikrotom dan diletakan pada preparat, dan penyimpanan dilakukan pada -20 derajat Celsius hingga sampel digunakan dengan teknik imunohistokimia. 
Ekspresi sel imun (molekul sel Il-4) dapat dilihat dengan teknik imunohistokimia melalui pelabelan secondary antibody conjugate biotin pada jaringan ikan yang telah dipapar protein imunogenik Vibrio harveyi secara invivo . Hasil uji IHC menunjukkan adanya perubahan struktur sel yakni bagian lisosom melalui pemeriksaan mikroskop inverted dapat dilihat pada Gambar 3.
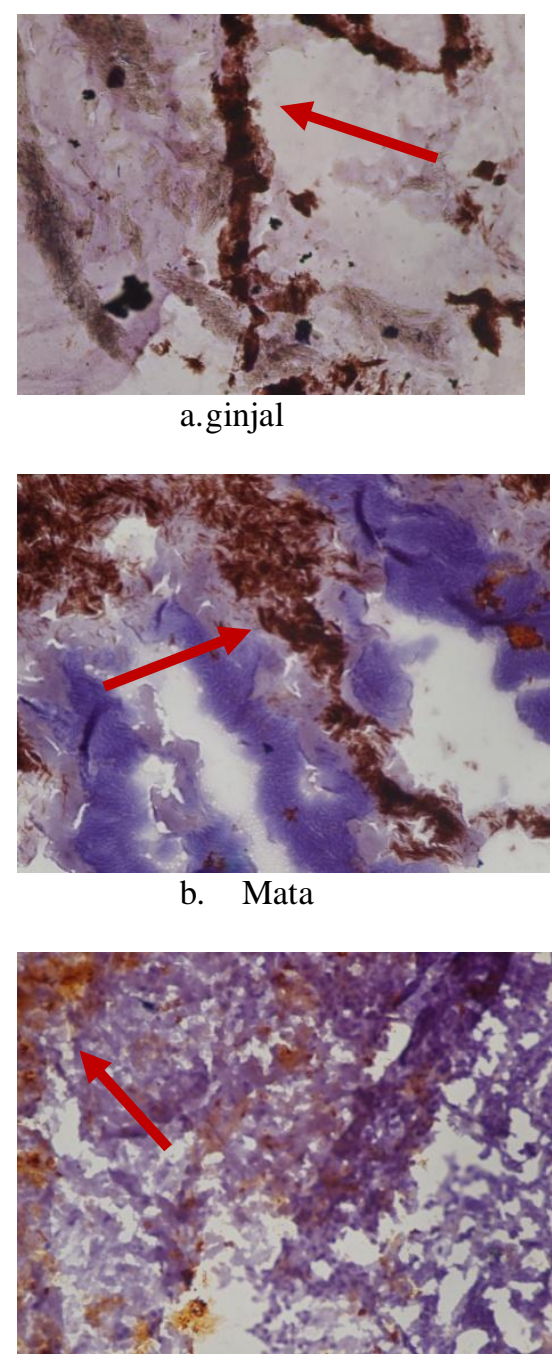

c.Otak

Dari hasil uji imunohistokimia dapat terlihat perubahan struktur sel yang ditandai dengan warna coklat keemasan, ini menunjukkan adanya reaksi silang antara protein imunogenik yang dipapar pada ikan kerapu tikus (Cromileptes altivelis) dalam bentuk sel imun (sel IL-4) dengan seconadary antibody anti IL-4 conjugate biotin pada organ otak, mata dan ginjal.

Pada organ mata, serangan Vibrio harveyi tersebut menyebabkan exopthalmia yaitu menurunnya kemampuan kornea (Austin, 2007). Pada ginjal, akan menyebabkan kemampuan sistem imun menurun sedangkan pada otak akan timbul gejala klinis berupa wierling atau berenang memutar karena keseimbangan ikan terganggu

Pada mata, interaksi reseptor diperankan oleh oleh Laminin. Laminin ditemukan pada permukaan ephitelia dan di retina. Laminin adalah komponen ECM yang termasuk kelompok Glikoprotein yang menjadi komponen utama dari semua Basement Membrane (BM), sedangkan ECMs digunakan oleh sel untuk adhesi, migrasi, dan selain itu hubungan ini akan meregulasi phenotype dan tingkah laku sel. Fungsi regulatori ini dimediasi oleh matrik sel reseptor pada sel, yang bertindak sebagai ikatan dan signal sel. Yang pada akhirnya terjadi exopthalmia (Austin, 2007)

Ginjal ikan memiliki bagian ginjal yang terpenting adalah head kidney (ginjal cranial) yang sebagian besar terdiri atas lympomyeloid compartment. Head kidney merupakan organ haematopoietic yang mempunyai peranan penting, seperti halnya pada sumsum tulang belakang vertebrata tingkat tinggi. Head kidney juga bertindak sebagai lympoid sekunder yang berperan penting dalam induksi dan elaborasi respon imun. Parenkim dari head kidney diedarkan diantara sistem sinusoid dan didukung oleh stroma dari ginjal. Stroma dari head kidney berfungsi untuk mendukung jaringan haematopoietic tetapi juga berperan penting dalam kekebalan spesifik dan membersihkan sel-sel yang rusak. Makrofag sinusoidal dan sel endothelial pada head kidney berpartisipasi dalam menangkap partikel dan substansi lain dari aliran darah, dimana renal berperan dalam filtrasi untuk menghilangkan partikel lain di darah. Head kidney adalah produsen antibodi dan mengakumulasikan melanomakrofag yang mampu menyimpan dan memelihara antigen dalam waktu yang lama (immunological memory) ( Press.C.McL, 1999)

Organ otak ikan terdiri dari 5 bagian utama yaitu lobus olfaktorius (olfactory bulb), Otak kecil (cerebrum), optik lobe, otak besar (cerebellum), dan medulla oblongata. Dimungkinkan bahwa $V$ harveyi menyerang bagian CNS (Central Nervous System) atau sistem saraf pusat sehingga gejala berupa wierling terjadi. Bakteri masuk dengan melalui beberapa cara yakni : 1. Invasi (penembusan) melawan penghalang anatomi berupa epitelium luar dan dalam yang dikenal dengan kulit. 2 . Transport axonal oleh neuron dari bagian perifer. 3. Masuk melalui saluran pernafasan atas kemudian melalui epitel olfactorius. 
Selanjutnya bakteri mengadakan multiplikasi dengan bantuan dari unsur-unsur bakteri sendiri dan unsur dari hospes/inang berupa biokimia untuk pertahanan, interaksi antara keduanya akan bersifat toksik bagi inang. CNS tersebut tersusun atas neuron dan sel glia (Virela and Gabriel, 2007).

Dijelaskan lebih lanjut bahwa setiap antigen ekstraseluler yang masuk ke dalam tubuh termasuk bakteri V. alginolyticus akan ditangkap oleh APC (antigen presenting cells) yang selanjutnya antigen tersebut dipecah menjadi molekul-molekul yang lebih kecil.

Molekul-molekul tersebut selanjutnya diekspresikan oleh molekul MHC II ke permukaan sel APC untuk dipresentasikan kepada sel Th2. Sel Th2 yang teraktivasi selanjutnya akan memproduksi sitokin-sitokin diantaranya IL2, IL4, IL6, dan IL10 untuk dijadikan sebagai sinyal kepada sel B. Sel B yang teraktivasi oleh sitokin-sitokin tersebut selanjutnya akan mengadakan proliferasi dan diferensiasi menjadi sel B plasma dan sel B memori. Sel plasma akan berperan untuk mensekresi antibodi yang spesifik terhadap antigen yang masuk sedangkan sel B memori akan mengekpresikan reseptor-reseptor yang spesifik terhadap antigen tersebut di permukaannya yang berperan untuk lebih mengenali antigen pada infeksi berikutnya (Abbas and Lichtman, 2005).

\section{Kesimpulan}

Hasil induksi protein imunogenik Vibrio harveyi pada ikan kerapu tikus uji dapat berfungsi untuk meningkatkan ekspresi sel imun yakni sel interleukin-4 (IL-4) yang ditandai dengan warna coklat keemasan pada jaringan ikan hasil uji dengan pemeriksaan secara kualitatif. Hal ini membuktiokan adanya reaksi silang antara protein imunogenik yang diinduksikan pada ikan kerapu tikus (Cromileptes altivelis) secara in vivo dan membentuk respon imun yakni sel IL-4 dengan yang ditandai dengan pelabelan sel imun (sel IL-4( dengan seconadary antibody anti IL-4 conjugate biotin pada jaringan otak, mata dan ginjal ikan kerapu secara visual kualitatif. Rekomkendasi penelitian ini adalah untuk melanjutkan penbelitian pada tingkat ekspresi genetik sel imun IL-4 untuk pengembangan diagnostik vibriosis secara cepat, walaupun telah digunakan analisis imunohistokimia.

Ucapan Terima kasih disampaikan kepada Kementrian Negara Riset Dan Teknologi yang telah mendanai riset ini melalui Program
Insentif Riset Dasar Tahun penelitian 20082009.

Daftar Pustaka

Abbas, A. K. and A. H. Lichtman. 2005. Cellular and Molecular Immunology, fifth edition, updated edition. Elsevier saunders, Pennsylvania.

Aslianti, T, B. Slamet dan G.S. Prasetyo. 2003. Aplikasi Budidaya Ikan Kerapu Bebek (Cromileptes altivelis) di Teluk Ekas Kabupaten Lombok Timur Badan Riset Kelautan dan Perikanan, Jakarta.

Austin,B.,and D.A Austin, 2007. Bacterial Fish Pathogen. $2^{\text {nd }}$ edition. Ellis Horwood Ltd., Chishester. Bandung.

Baratawidjaja, Karnen Garna, 1996. Immunologi Dasar. Fakultas Kedokteran Universitas Indonesia. Gaya Baru. Jakarta.

Jun L, Norman Y.S. Woo.,2003. Pathogenicity of Vibrios in Fish: an Overview, Journal of Ocean University of Qingdao (Oceanic and Coastal Sea Research) October 31,2003, Vol.2, No.2

Press C. Mcl. and Evensen, 1998. The Morphology of The Immune System in Teleost Fshes. Fish \& Shellfish Immunology 1999. 9, 309-318. Academic Pres

Yanuhar, U. 2008 Pengembangan Vaksin Berbasis Peptida untuk Penyiapan Bibit Unggul Ikan Kerapu Tikus. Laporan Penelitian Program Insentif Riset Dasar . KMNRT. Tidak Dipublikasikan .

Virella, Gabriel. 2007. Basic Immunology In Virella, G. (Ed). Medical Immunology sixth edition. Informa Healthcare, New York. 